\title{
KONTROVERSI REPAIR RUPTUR TENDO ACHILLES
}

\author{
Abd. Rahman \\ Fakultas Kedokteran dan Ilmu Kesehatan (FKIK) UIN Alauddin Makassar \\ abdrahman@uin-alauddin.ac.id
}

\begin{abstract}
Abstrak
Tendo Achilles merupakan tendo yang paling tebal dan kuat pada tubuh yang berfungsi sangat penting untuk stabilitas waktu berjalan. Ruptur tendo Achilles sering terjadi pada usia dekade keempat dan paling banyak terjadi secara spontan, baik sewaktu berolahraga, melompat, atau jatuh dari ketinggian. Penanganan ruptur tendo Achilles masih merupakan isu kontroversial. Penanganan operasi memiliki kekuatan otot yang lebih kuat dibanding non operasi sehingga insiden untuk cedera kembali lebih sedikit. Penanganan operasi telah menjadi pilihan pada atlit, orang-orang muda dan pasien ruptur yang lama. Penanganan non operasi dengan immobilisasi gips dilakukan untuk menghindari bahaya dari komplikasi operasi dan anestesi, namun immobilisasi gips yang lama akan menimbulkan atrofi otot betis, kekakuan sendi, memperlama waktu rehabilitasi dan kehilangan waktu kerja yang cukup lama. Tujuan penanganan ruptur tendo Achilles adalah untuk mengembalikan panjang normal dan ketegangan pada tendo dan memungkinkan pasien untuk melakukan apa yang dapat dilakukan sebelum cedera. Penanganan mencerminkan keseimbangan antara perlindungan dan mobilisasi segera. Pilihan penanganan ruptur tendo Achilles menurut beberapa pendapat ahli bergantung pada pendekatan apa yang disukai.
\end{abstract}

Kata Kunci : Ruptur tendo Achilles, penanganan operasi, penanganan non operasi

\section{PENDAHULUAN}

Tendo Achilles adalah tendo yang paling tebal dan kuat dari tendo yang ada pada tubuh manusia yang fungsinya sangat penting untuk stabilitas waktu berjalan. Winer dan Lipscomb melaporkan cedera tendon Achilles adalah ketiga terbanyak dari cedera tendo yang sering dijumpai, dan ini banyak didapati pada usia dekade keempat. Lipscomb melaporkan cedera tendo Achilles adalah terbanyak secara spontan, baik sewaktu berolahraga, melompat atau jatuh dari ketinggian. Mendiagnosis suatu cedera tendo Achilles dengan pemeriksaan fisik, dimana kaki yang mengalami cedera di dorsofleksikan sehingga kita akan dapat meraba defek dari tendo yang mengalami cedera. ${ }^{1}$

Penanganan cedera tendo Achilles masih merupakan isu yang kontroversial. Para penulis yang mengusulkan tindakan konservatif dengan immobilisasi gips dengan alasan untuk menghindari bahaya dari komplikasi anastesi dan komplikasi operasi berupa infeksi dan parut. Sedangkan penulis lain menunjukkan bahwa yang ditangani secara operasi mempunyai kekuatan otot yang lebih kuat dari yang non operasi sehingga insiden untuk cedera kembali setelah intervensi bedah juga lebih sedikit. Pada tindakan immobilisasi dengan gips yang berlama-lama pada tungkai bawah setelah reparasi tendon Achilles ataupun hanya 
dengan tindakan konservatif saja akan menimbulkan banyak problem yaitu berupa atrofi otot betis, kekakuan sendi, memperlama waktu rehabilitasi dan kehilangan waktu kerja yang cukup lama. ${ }^{1}$

Walaupun ruptur tendo Achilles relatif sering terjadi, namun insidens pada populasi umum masih sukar untuk ditentukan. Leppilahti dkk., pada tahun 1994 memperkirakan ruptur tendo Achilles di kota besar Oulu, Finlandia, sekitar 18 per 100,000 penduduk setiap tahun. Ruptur tendo Achilles merupakan ruptur yang paling sering ditemukan pada atlit. Besaran ruptur tendo Achilles antara, 44 persen (12 dari 27) sampai 83 persen (92 dari 111) terjadi selama olahraga. Di negara-negara Scandinavia, pemain bulu tangkis memiliki risiko lebih tinggi; suatu studi, 58 dari 111 pasien (52 persen) mengalami ruptur tendo Achilles pada waktu akhir permainan. 2,3,4

Ruptur tendo Achilles lebih sering pada laki-laki daripada wanita berkisar antara 1.7:1 sampai 12:1 (30:1). Hal ini menunjukkan semakin besar kebiasaan lakilaki dibanding wanita dalam kegiatan olahraga, walaupun mungkin ada faktor lain yang belum diketahui. Tendo Achilles kiri lebih sering mengalami ruptur dibanding kanan mungkin oleh karena kebanyakan orang adalah sisi kanan yang dominan dan bertolak dengan tungkai kiri. Ruptur tendo Achilles pada laki-laki terjadi pada dekade ketiga atau keempat. ${ }^{2,3,4,5,6,7}$

Lokasi cedera dari tendon Achilles yang spontan umumnya terjadi antara 2-6 cm proksimal dari tempat insersi tendon Achilles di kalkaneus. Menurut Lagergen dan Lindholm di daerah ini terjadi hipovaskularisasi dengan semakin meningkatnya usia dan juga di daerah ini sering mendapat trauma yang berulang-ulang sehingga akan menyebabkan elastisitas dari tendo menjadi berkurang. ${ }^{1,6,8}$

Ruptur tendo Achilles secara spontan telah dihubungkan dengan banyak gangguan seperti inflamasi dan proses autoimmun, kelainan genetik kolagen, penyakit infeksi, dan kelainan neurologik. Suatu proses penyakit dapat mempengaruhi tendo ruptur secara spontan dari trauma minor. Aliran darah dalam tendo berkurang dengan meningkatnya umur, dan daerah tendo Achilles secara khas cenderung untuk ruptur karena relatif avaskular. Pada studi Arner dkk., secara histologi ditemukan terjadi degenerasi kollagen pada semua (74 kasus) yang diteliti. Di mana, sekitar 2/3 spesimen diperoleh lebih dari 2 hari setelah terjadi ruptur. Davidsson dan Salo melaporkan terdapat tanda perubahan degeneratif pada 2 pasien ruptur tendo yang telah dioperasi pada 
hari terjadinya cedera. Pada studi Waterston, menunjukkan bahwa semua tendo yang telah dioperasi dalam 24 jam setelah cedera menunjukkan tanda perubahan degeneratif dan gangguan kollagen, ini sesuai dengan studi terbaru yang lainnya. ${ }^{2}$

Penyakit tertentu (seperti arthritis dan diabetes) dan obat-obatan (seperti kortikosteroid dan beberapa antibiotik) juga dapat meningkatkan risiko ruptur. Orang yang sering mengalami ruptur tendo Achilles antara lain atlet, usia tua, riwayat ruptur Achilles tendo sebelumnya, suntikan tendo sebelumnya atau penggunaan kuinolon, perubahan ekstrim dalam intensitas latihan atau tingkat aktivitas, dan partisipasi dalam aktivitas baru. ${ }^{5}$

Antibiotik fluorokuinolon seperti ciprofloxacin dan glukokortikoid telah dikaitkan dengan peningkatan risiko ruptur tendo Achilles. Suntikan steroid langsung ke tendo juga telah dikaitkan sebagai faktor risiko. ${ }^{5}$

\section{Mekanisme Ruptur}

Ruptur tendo Achilles sering terjadi pada saat berlari, melompat, atau berolahraga seperti main tenis, bola voli, bola basket, dan badminton. Penyebab yang paling sering menyebabkan ruptur tendo Achilles adalah gerakan secara tiba-tiba fleksi plantar, tak terduga dorsofleksi, atau dorsofleksi paksa pergelangan kaki melewati kisaran normal gerak. Mekanisme lain yaitu trauma langsung tiba-tiba tendo, atau aktivasi tiba-tiba dari Achilles setelah atrofi dari periode lama tidak aktif. ${ }^{4,9}$

Arner dan Lindholm, menggolongkan trauma yang menyebabkan ruptur pada 92 pasien ke dalam 3 kategori. Pertama, pada saat bertolak dengan weight-bearing kaki depan dengan lutut lurus. Gerakan ini dapat dilihat pada saat start lomba lari jarak pendek dan gerakan melompat seperti olahraga basket. Mekanisme ini mencatat 53\% menyebabkan terjadinya ruptur. Kedua, dorsiflexi mendadak pada ankle seperti terjadi pada saat kaki terselip masuk ke dalam lubang atau terjatuh dari tangga. Mekanisme ini mencatat $17 \%$ menyebabkan terjadinya ruptur. Ketiga, dorsiflexi paksa dari plantar kaki, seperti terjatuh dari ketinggian. Mekanisme ini dilaporkan terjadi $10 \%$ dari pasien. Mekanisme yang pasti untuk pasien lainnya tidak diketahui. ${ }^{2}$

Diagnosis berdasarkan riwayat klinis dan pemeriksaan fisik, pada ruptur tendo Achilles secara khas pasien merasakan nyeri mendadak pada tungkai yang cedera, dan mereka sering melaporkan bahwa, pada saat terjadi cedera, mereka merasa seperti diserang sesuatu atau ditembak pada bagian belakang tungkai bawah. Beberapa pasien 
mendengar suara tembakan, adanya robekan pada saat berolahraga. Penderita tidak dapat jalan, nyeri tekan dan pembengkakan pada Achilles, terjadi kelemahan atau kekakuan pada ankle yang terkena. Ruptur tendo Achilles berhubungan dengan kurangnya latihan pemanasan sebelum berolahraga. ${ }^{4,9,10,11}$

Awalnya nyeri, bengkak, dan kekakuan bisa diikuti oleh memar dan kelemahan. Berdiri berjinjit dan mendorong saat berjalan akan menjadi sulit. Berjalan biasanya akan sangat terganggu, pasien tidak akan mampu untuk melangkah dengan menggunakan kaki yang cedera. Pasien juga tidak mampu untuk berdiri pada ujung kaki itu, dan flantarplexi akan terganggu. Nyeri hebat dan pembengkakan adalah gejala paling sering. ${ }^{11}$

Pada pemeriksaan fisik didapatkan edema dan bruising, dan pembengkakan, teraba adanya "gap" tepat di atas tumit. Lokasi ruptur biasanya $2-6 \mathrm{~cm}$ proximal dari insersi tendo. Krueger-Franke dkk., telah mengukur lokasi ruptur intraoperatif pada 303 pasien dan memastikan bahwa, rata-rata $4.78 \mathrm{~cm}$ proximal dari insersi tendo pada calcaneus. ${ }^{4,9,10}$

Foto Polos

Foto lateral ankle dapat digunakan untuk mendiagnosis ruptur tendo Achilles.
Pada ruptur tendo Achilles, Triangle Kager's, ruang segi tiga yang berisi lemak di anterior tendo Achilles dan antara aspek posterior dari tibia dan superior dari calcaneus, hilang bentuk regulernya. Toygar's sign meliputi pengukuran sudut dari posterior skin-surface kurva dilihat pada hasil sinar x. Sudut 130150 derajat menandakan ruptur tendo Achilles. Arner dkk., menemukan kelainan bentuk di sekeliling dari segmen distal tendo menyebabkan hilangnya tonus merupakan perubahan radiografis yang paling sering dihubungkan dengan ruptur tendo Achilles. ${ }^{2}$

Foto polos juga dapat digunakan untuk mengidentifikasi secara tidak langsung tear drops Achilles. Foto polos digunakan untuk menganalisis titik cedera. Tapi tidak efektif dalam mengidentifikasi cedera pada jaringan lunak. Foto polos lebih untuk mengesampingkan kemungkinan cedera lain seperti fraktur calcaneous, tendo, bengkak, dan kalsifikasi. ${ }^{2,9}$

Ultrasonography (USG)

Secara normal tendo Achilles tampak sebagai gambaran hypoechogenic. Ruptur tendo Achilles tampak sebagai suatu ruang hampa akustik dengan tepi tebal, tidak beraturan. USG dapat digunakan untuk menentukan ketebalan tendon, karakter, dan terdapatnya tear drop. ${ }^{2,9}$

Magnetic Resonance Imaging (MRI) 
MRI dapat digunakan untuk membedakan ruptur inkomplit dari degenerasi tendo Achilles, dan MRI juga dapat membedakan antara paratenonitis, tendinosis, dan bursitis. ${ }^{2}$

\section{PENATALAKSANAAN}

Tujuan pengobatan adalah untuk mengembalikan panjang normal dan ketegangan pada tendo dan memungkinkan pasien untuk melakukan apa yang dapat dilakukan sebelum cedera. Pengobatan mencerminkan keseimbangan antara perlindungan dan mobilisasi segera. Perlindungan ini diperlukan untuk memberi waktu proses penyembuhan dan untuk mencegah cedera ulang. Mobilisasi kaki dan pergelangan kaki diperlukan untuk mencegah kekakuan dan hilangnya tonus otot. ${ }^{9}$

Pilihan pengobatan untuk ruptur tendo Achilles meliputi pendekatan bedah dan non bedah. Beberapa pendapat profesi medis dibagi menurut pendekatan apa yang disukai.

Banyak teknik dan prosedur yang telah diuraikan pada penanganan ruptur tendo Achilles akut, dan dibagi dalam 3 kelompok yaitu operasi terbuka, operasi perkutaneus, dan non operasi. Tidak ada protokol yang disepakati, pilihannya bergantung pada pilihan ahli bedah dan pasien. Penanganan non operasi mempunyai para pendukung, tetapi penanganan operasi telah menjadi metoda pilihan pada dua dekade terakhir untuk atlit dan orang-orang muda dan untuk pasien ruptur yang lama. Ruptur akut pada non-athlet dapat dilakukan nonoperatif. Sebagai contoh, pada penelitian prospektif, randomisasi, 40 pasien ruptur tendo Achilles komplit diimmobilisasi dengan gips selama 8 minggu atau immobilisasi dengan gips selama 3 minggu diikuti dengan mobilisasi segera dikontrol dengan Sheffield splint, di mana ankle-foot orthosis pegangan pada ankle dengan plantar flexi 15 derajat tetapi diikuti dengan beberapa gerakan pada metatarsophalangeal joint. Dengan splint, gerakan pada ankle dapat dikontrol selama fisioterapi. Pasien dengan bidai dapat dilakukan mobilisasi lebih cepat. Jangkauan dorsiflexi dari ankle meningkat dengan cepat setelah perawatan dengan splint, dan pasien kembali beraktivitas normal lebih cepat. Pemulihan kekuatan plantar flexi adalah sama pada kedua kelompok, dan tidak ada pasien mempunyai perpanjangan tendo yang berlebihan. Satu pasien mengalami ruptur berulang pada masing-masing kelompok..$^{2,15}$ Dilaporkan oleh beberapa penulis bahwa penanganan cedera tendon Achilles selama 8 minggu dan peninggian tumit rata rata 6 minggu, ternyata mempunyai dampak 
tidak nyaman bagi penderita, dimana waktu immobilisasi gips yang lama (14 minggu) menyebabkan otot -otot betis atrofi dan kekakuan sendi kaki yang tentunya memperlama waktu rehabilitasi dan penderita kehilangan kerja lama. Kemampuan untuk sembuh sempurna merupakan kepentingan penderita. ${ }^{1,15}$

\section{Operasi Terbuka}

Banyak teknik operasi yang digunakan untuk memperbaiki ruptur tendo Achilles mulai dari jahitan sederhana end to end, dengan jahitan tipe Bunnell atau Kessler, sampai repair yang lebih kompleks dengan penggunaan penguatan fascia atau graft tendo. Tendo implant, menggunakan material seperti serabut polymer-carbon yang dapat diserap, Marlex mesh ( monofilament polypropylene) dan protesa tendo collagen, telah digunakan. Jahitan end-to-end dapat dilakukan dengan lokal anestesi, yang telah dimodifikasi dengan menggunakan material seperti Dacron vaskuler graft. Studi pada anjing telah menunjukkan bahwa Dacron dapat membantu pertumbuhan jaringan fibrous dan memudahkan approksimasi dari tendo, menyebabkan lebih sedikit tegangan di lokasi repair dibanding jahitan standard. Bagaimanapun, maturasi collagen yang baik mempengaruhi siklus ketegangan. Oleh karena itu, ketiadaan tegangan pada lokasi repair mungkin tidak menguntungkan.,16

Beberapa penulis telah menentang operasi repair, mereka mengatakan bahwa operasi memiliki angka komplikasi yang tinggi yang merugikan. Arner dan Lindholm, pada 86 pasien ruptur tendo Achilles yang dilakukan operasi, dilaporkan terdapat $24 \%$ yang mengalami komplikasi, termasuk 2 mengalami deep-vein trombosis, salah satu mengakibatkan embolism paru dan menyebabkan kematian; 3 mengalami infeksi; 11 mengalami necrosis;dan 4 ruptur berulang. Studi terakhir menunjukkan angka komplikasi yang lebih rendah.Soldatis, dkk., pada studi 23 pasien yang dilakukan operasi, dilaporkan hanya 2 yang mengalami komplikasi, keduanya mengalami penyembuhan luka yang tergangu. Angka komplikasi yang rendah disebabkan pengalaman operator yang lebih banyak dan teknik operasi yang lebih baik. Bagaimanapun, permasalahan luka sering tak terduga pada operasi, seperti pada insisi longitudinal yang sering melewati kulit yang vaskularisasi jelek. Pada studi 40 pasien, Aldam menggunakan insisi transversal saja di distal gap pada tendo dan dilaporkan hanya satu mengalami gangguan luka. ${ }^{2}$

Setelah operasi, tungkai diimmobilisasi dengan gips selama 4-6 
minggu. Beberapa ahli bedah telah mendukung penggunaan orthosis fungsional setelah beberapa hari diimmobilisasi dengan gips. Orthosis ini memungkinkan untuk plantar flexion tetapi membatasi dorsiflexion dan dirancang untuk mencegah atropi triceps surae. Beberapa ahli bedah menganjurkan gerak bebas pada ankle tetapi tidak ada weight bearing setelah operasi. ${ }^{2,13,17}$

Terdapat kontroversi yang belum selesai tentang penggunaan teknik operasi terbuka pada ruptur tendo Achilles, dengan beberapa penyelidikan melaporkan tingginya angka komplikasi dan angka ruptur berulang lebih sedikit. $^{2,18}$

Beberapa ahli bedah berpendapat dengan bedah segera tendon yang ruptur memberi perbaikan yang bermanfaat. Pilihan pembedahan memberi risiko yang lebih kecil secara signifikan rupture berulang dibandingkan dengan non-pembedahan $(5 \%$ vs $15 \%)$. Tentu saja, pembedahan memberi risiko yang relatif lebih tinggi mortalitas perioperatif dan morbiditas misalnya infeksi termasuk MRSA, perdarahan, deep vein thrombosis, efek anestesi lama, dan lainlain. $^{2}$

\section{Operasi perkutan}

$\mathrm{Bu}$ dan Griffith, mengembangkan suatu metoda untuk repair percutaneus sebagai suatu kompromi antara metode operasi terbuka dan non operatif. Teknik ini membuat 6 insisi kecil pada sepanjang medial dan lateral batas tendo dan kemudian melakukan jahitan melalui tendo dengan menggunakan insisi ini. Pada 18 pasien dengan menggunakan teknik ini, $\mathrm{Bu}$ dan Griffith melaporkan hanya dua mengalami komplikasi kulit non infeksi dan tidak ada ruptur berulang. Rowley dan Scotland, menguraikan 24 pasien ruptur tendo Achilles; 14 ditangani dengan immobilisasi gips saja, dengan ankle posisi equinus, dan 10 ditangani dengan repair percutaneus. Satu pasien yang dilakukan repair percutaneus mengalami entrapment nervus sural, tetapi tidak ada komplikasi lain ditemui. Pasien yang dilakukan jahitan lebih mungkin untuk memperoleh kekuatan plantar flexi hampir normal dan mereka juga kembali ke aktivitas lebih cepat dibanding dengan kelompok dilakukan dengan gips saja., ${ }^{2,19}$

Pada operasi perkutan tendo Achilles sedikit lebih tebal dibanding dengan prosedur operasi terbuka. Dan beberapa pasien menyukai ini, makin baik penampilan yang didapat. Banyak studi menunjukkan angka ruptur ulangan setelah repair percutaneous lebih tinggi dibanding dengan setelah operasi terbuka. Juga, terjadi gangguan nervus sural telah dilaporkan, terjadi parastesia persisten dan perlu dilakukan 
operasi explorasi untuk mengangkat jahitan dan membebaskan nervus. ${ }^{2}$

Pada operasi perkutan, ahli bedah membuat sayatan kecil beberapa, bukan dari satu irisan besar, dan menambalkan tendon kembali bersama-sama melalui sayatan. Pembedahan mungkin tertunda selama sekitar seminggu setelah pecah untuk membiarkan pembengkakan turun. Untuk pasien yang menetap dan mereka yang telah vasculopathy atau risiko untuk penyembuhan miskin, perbaikan bedah perkutan mungkin pilihan pengobatan yang lebih baik daripada perbaikan bedah terbuka. ${ }^{9}$

\section{Perawatan Non operatif}

Penanganan non-operasi secara tradisional dipilih untuk ruptur kecil, orang tua, pasien yang kurang aktif, dan mereka dengan alasan kondisi medis yang memungkinkan terhindar dari tindakan operasi. Penanganan secara tradisional ini terdiri dari pemasangan gips selama 6-8 minggu dengan posisi flantar extensi (untuk melawan ujung ruptur tendon). Tetapi studi terbaru telah memberi hasil yang jauh lebih unggul dengan rehabilitasi cepat menggunakan sepatu tetap atau berengsel. ${ }^{2,11}$

Perawatan non operasi yang paling sering digunakan adalah immobilisasi dengan gips, biasanya selama 6-8 minggu. Immobilisasi telah didukung oleh mereka yang berpikir bahwa hasilnya sama dengan tindakan operasi. Ketika tendo Achilles ruptur, paratenon biasanya masih intak. Stripping paratenon selama operasi mengurangi jaringan reaktif yang terjadi kemudian pada daerah cedera. Penulis itu mengusulkan bahwa operasi pada ruptur tendo Achilles sebaiknya dihindari, sebab paratenon memberi suplai darah pada tendo yang rusak. ${ }^{2}$

Lea dan Smith, pada studi 55 pasien ruptur tendo Achilles spontan dilakukan immobilisasi dengan gips selama 8 minggu, dilaporkan 7 (13\%) pasien mengalami ruptur berulang dan 3 pasien yang tidak puas dengan hasil itu. Hasil ini berbeda bermakna studi Persson dan Wredmark, mereka melaporkan 20 pasien yang ditangani secara non operasi. Tujuh pasien mengalami ruptur berulang, dan 7 pasien yang tidak mengalami ruptur berulang tidaklah cukup dengan hasil tersebut. Walaupun fungsi setelah perawatan non-operatif umumnya baik, kejadian ruptur berulang yang tinggi dipertimbangkan tak dapat diterima. Tujuan utama penangan ruptur tendo Achilles adalah menghindari perpanjangan tendo, dan ini tidak dapat dicapai dengan penaganan non operasi. ${ }^{2}$

Baru-baru ini, atas dasar hasil yang dilaporkan Mc Comis dkk., dengan penggunaan bracing fungsional sesudah 
operasi, 5 pasien yang ditangani secara non operatif dengan fungsional bracing untuk memperbaiki ruptur tendo Achilles. Mereka mendapat hasil fungsional baik, membuktikan bahwa, untuk pilihan pasien, non operatif dengan bracing fungsional dapat menjadi alternatif pada operasi intervensi atau dengan menggunakan plester gips pada penanganan ruptur tendo Achilles akut. ${ }^{2}$

Beberapa pasien, terutama yang lebih tua, tampak ruptur yang sudah berjalan lama yang ditemukan secara kebetulan. Pasien ini sering beradaptasi dengan kecacatan, tetapi mereka diingatkan bahwa operasi perlu dilakukan jika gejala yang disebabkan ruptur tendo Achilles bertambah buruk. Pasien seperti ini diikuti pada waktu yang tertentu, tetapi mereka pada umumnya tidak memerlukan penanganan tambahan.,20

\section{Perbandingan antara operasi dan non operasi}

Hasil perbandingan penanganan ruptur tendo Achilles antara operasi dan non operasi sering dilakukan namun hanya sedikit yang dilakukan uji kontrol, prospektif, dan randomisasi. Masalah utama adalah kurangnya protap yang valid dan dapat diterima untuk mengevaluasi hasil repair ruptur tendo Achilles baik secara subyektif maupun objektif. ${ }^{2}$
Gilles dan Chalmers mengukur panjang flexi plantar setelah penanganan operasi dan non operasi pada ruptur tendo Achilles. Terdapat sedikit perbedaaan yang ditemukan antara dua kelompok, dimana hasil dari penanganan operasi tidak lebih baik untuk menggaransi munculnya risiko yang berhubungan dengan anestesi dan operasi. Inglis $\mathrm{dkk}$, mengamati 44 pasien yang menjalani operasi dan 23 pasien tanpa operasi. Tidak ditemukan adanya ruptur berulang pada pasien yang menjalani operasi, namun terdapat 9 pasien $(39 \%)$ pada pasien yang tanpa operasi yang mengalami ruptur ulangan. Pada evaluasi kekuatan, pasien yang menjalani operasi menunjukkan kekuatan dan daya tahan lebih baik, sehingga disarankan penanganan dengan jalan ini, Mistord melakukan uji prospektif dan randomisasi terhadap 105 pasien, 45 pasien dengan operasi dan 60 pasien tanpa operasi. Pada pasien dengan operasi angka ruptur ulangan $4 \%$ pada pasien tanpa operasi $8 \%$, namun demikian terdapat sejumlah besar komplikasi sekunder pada pasien dengan operasi. Pasien yang tanpa operasi ditemukan hanya sedikit absen kerja, kekakuan sendi ankle tapi mempunyai kekuatan sama dengan yang operasi. Mistord merekomendasi penanganan tanpa operasi, hanya sedikit perbedaan fungsional antara 2 kelompok 
dimana penanganan dengan operasi lebih banyak menyebabkan komplikasi. Pada penelitian yang dilakukan oleh Charden dkk, terhadap 76 pasien tanpa operasi dan 56 pasien dengan operasi. Dilakukan perbandingan antara pasien yang diperiksa < 48 jam setelah cedera dengan pasien yang diperiksa $>48$ jam setelah cedera. Secara keseluruhan, pasien tanpa operasi ditemukan 4\% yang menderita komplikasi, pasien dengan operasi ditemukan $17 \%$ yang mengalami komplikasi. Hasil subyektif juga lebih baik pada kelompok tanpa operasi. Penulis menyimpulkan pasien yang diperiksa dalam waktu $<48$ jam setelah cedera sebaiknya ditangani tanpa operasi, dengan 8 minggu immobilisasi dengan gips namun pasien yang diperiksa dalam waktu seminggu atau lebih setelah cedera, sebaiknya dioperasi. $^{2}$

Pada uji randomisasi, 22 pasien yang ditangani dengan operasi dibandingkan dengan 28 pasien tanpa operasi; kedua kelompok menjalani terapi fungsional dengan sepatu boot terbaru. Tidak ada perbandingan signifikan antara kedua kelompok dari segi hasil fungsional dan penyembuhannya. Terapi fungsional pada kedua kelompok memperpendek masa rehabilitasi.
Kellam dkk, melakukan review pada literatur dan mengidentifikasi 609 pasien yang dioperasi, dan 208 pasien tanpa operasi. Ruptur ulangan ditemukan pada $1 \%$ pasien dengan operasi, dibandingkan dengan $18 \%$ pada pasien tanpa operasi. $83 \%$ pasien dengan opearasi dan $69 \%$ pasien yang immobilisasi dengan gips kembali mengalami cedera ulang. $93 \%$ pasien dengan operasi dan $66 \%$ pasien tanpa operasi menyatakan puas dengan penanganan tersebut. $^{2}$

Cetti dkk, pada studi prospektif dan randomisasi melaporkan bahwa 56 pasien dengan operasi dan 55 pasien tanpa operasi. Angka komplikasi dan ruptur berulang 9\% dan $5 \%$ pada pasien operasi dan $16 \%$ dan $15 \%$ pada pasien tanpa operasi. Namun demikian, tidak terdapat perbedaan signifikan pada kedua kelompok. Penulis juga melakukan review pada literatur dan identifikasi pada 4597 ruptur tendo Achilles. Penanganan dengan operasi berhubungan dengan angka komplikasi dan ruptur ulangan dibandingkamn dengan tanpa operasi. Cetti dkk, menyimpulkan bahwa operasi merupakan metode pilihan namun metode non operasi merupakan alternatif yang dapat diterima. $^{2}$

Yang terbaru, Lo dkk., melakukan review kuantitatif pada semua studi 
penanganan ruptur tendo Achilles pada literatur berbahasa Inggris yang dipublikasikan antara tahun 1959-1997 untuk menentukan penanganan optimal pada ruptur akut. Semua artikel yang diidentifikasi secara independen yang ditulis oleh setidaknya 3 atau 4 penulis untuk menentukan eligibilitas masing-masing studi berdasarkan kriteria yang sudah ditentukan. Studi yang tereligibilitas direview secara independen, data disajikan dengan menggunakan format yang telah distandarisasi. inkonsistensi terhadap data diatasi dengan diskusi dan voting suara mayoritas. Hasil utama yang dikeluarkan menyangkut kekuatan, waktu sampai pasien kembali bekerja, frekuensi kembali berolahraga, angka ruptur ulangan, dan komplikasi. Komplikasi dikelompokkan menjadi komplikasi besar, sedang dan kecil. Lo dkk, mengidentifikasi total 742 pasien dengan operasi dan 248 pasien tanpa operasi. Komplikasi ruptur ulangan 3\% pada pasien dengan operasi dan $12 \%$ pada pasien tanpa operasi $(\mathrm{p}<0,001)$. Meskipun angka ruptur ulangan setelah operasi lebih sedikit dibandingkan dengan tanpa operasi, namun angka komplikasi ringan dan sedang yang berhubungan dengan operasi 20 kali lebih besar pada sejumlah laporan.

Sebagai kesimpulan, penanganan seharusnya perindividu tergantung pada pilihan dan kesehatan pasien. Jika status penampilan optimal, maka penanganan operasi mungkin menjadi pilihan. Tindakan operasi dilakukan pada atlet dan pada pasien yang memiliki aktivitas yang tinggi. Operasi perkutan dianjurkan pada pasien yang tidak mau dilakukan dengan repair terbuka, untuk alasan kosmetik. Penanganan non operasi sebaiknya dilakukan pada pasien orang tua yang tidak memperoleh keuntungan lebih dengan prosedur operasi. ${ }^{2}$

\section{Perawatan Post Operasi}

Secara normal, pasien pulang pada hari operasi atau hari berikutnya, setelah fisioterapi orthopaedic telah instruksikan penggunaan crutches. Pasien diijinkan untuk weight bearing pada tungkai dapat dimaklumi, tetapi mereka harus diberitahu untuk menjaga pengaruh elevasi tungkai untuk mencegah pembengkakan sesudah operasi. Pasien difollow up saat rawat jalan selama interval 2 minggu, dan gips dilepas 6 mingu setelah operasi. Jika gips dipasang pada ankle posisi equinus, gips diubah pada 2 dan 4 minggu, dengan ankle diposisikan secara berangsur-angsur meningkat ke dorsiflexi sampai suatu plantigrade posisi dicapai. Gips dilepas seluruhnya 6 minggu setelah operasi. ${ }^{2}$

Pasien diijinkan weight-bearing parsial dan secara bertahap latihan 
meregangkan dan memperkuat tendo, terus meningkat frekwensi sampai batas yang ditoleransi, hanya setelah gips dilepas. Secara bertahap, pasien mulai weight bearing penuh pada 8-10 minggu setelah operasi.

Selama masa immobilisasi gips, pasien dianjurkan untuk melakukan gerakan isometrik halus pada kompleks gastrocnemius-soleus setelah weight-bearing telah menjadi comfortable. Setelah gips dilepas, pasien dapat dimobilisasi pada ankle dibawa bimbingan ahli fisioterapi. Dua minggu setelah gips dilepas, bersepeda dan berenang dapat dimulai dan dilanjutkan dengan latihan mobilisasi pada ankle. Pasien dianjurkan untuk meningkatkan frekwensi program latihan sendiri. Pasien secara normal mampu kembali ke aktivitas olahraga pada bulan ketiga atau keempat sesudah operasi. $^{2,20}$

Penanganan Post operasi pada Atlit

Perawatan yang menghindari immobilisasi pada ankle harus dipertimbangkan untuk atlit dan dengan motivasi yang baik, pasien dapat menerima. Pasien ini dilakukan dengan gips Paris slab pada anterior bawah lutut dengan ankle posisi equinus. Pasien dipulangkan pada hari operasi atau hari berikutnya, dan mereka diijinkan toe-touch weight-bearing pada tungkai dapat dimaklumi. Mereka dianjurkan untuk menjaga agar tungkai elevasi selama mungkin. Pada 48-72 jam setelah operasi, di mana bengkak sesudah operasi telah berkurang, slab Paris pada anterior bawah lutut dapat diganti dengan slab sintesis dengan ankle pada posisi equinus. Slab dijaga pada tempatnya dengan elastic bandage, plantar flexi pada ankle, dengan dorsoflexi terbatas pada foot-piece dari slab. Pasien dianjurkan weight-bearing yang dapat ditoleransi dengan crutches. Slab diubah pada minggu kedua dan keempat sesudah operasi, sedemikian sehingga ankle dapat dorsiflexi sampai netral pada minggu keempat sesudah operasi. Pembatasan dorsofleksi berlanjut sampai 6 minggu, sampai slab dilepas. Atlet dengan motivasi yang baik mematuhi protokol sesudah operasi secara normal dapat kembali ke aktivitas olahraga 6-8 minggu setelah slab anterior dilepas. $^{2}$

\section{KESIMPULAN}

Tujuan penanganan ruptur tendo Achilles adalah untuk mengembalikan panjang normal dan ketegangan pada tendo dan memungkinkan pasien untuk melakukan apa yang dapat dilakukan sebelum cedera. Pengobatan mencerminkan keseimbangan antara perlindungan dan mobilisasi segera. Pilihan penanganan ruptur tendo Achilles 
menurut beberapa pendapat ahli bergantung pada pendekatan apa yang disukai.

\section{DAFTAR PUSTAKA}

1. Moesbar N. Penanganan Cedera Tendon Achilles dengan Mersilene Tape. Majalah Kedokteran Nusantara,Vol 39, No 3, Jakarta, 2006; 202-06

2. Maffuli N.; Rupture of the Achilles Tendon in The Journal of Bone and Joint Surgery, vol. 81-A, No.7, 1999, p. 101931

3. Young JS, et.al. Achilles Tendon Rupture Generalities. In: The Achilles Tendon, London :Springer; 2007, p. 141147.

4. Chairuddin R. Pengantar Ilmu Bedah Ortopedi, edisi kedua. Makassar; Bintang Lamumpatue; 2003, h 463.

5. Jacobs B, et. al.; Achilles Tendon Rupture in eMedicine Sport Medicine, 2009

6. Salter RB. Musculoskeletal Injuries. In:Textbook of Disorders and Injuries of the Musculoskeletal System, 3 rd ed., Jakarta; Orthopaedi FKUI, Jakarta; 2008, p. 610-11

7. Es, at.al. Repair of Acute Achilles Tendon Rupture Using a Double-ended needle. Journal of Orthopaedic Surgery, 2006

8. Canale, Beaty. Rupture of Muscles and Tendons. In: Campbell's Operative Orthopaedics, 11 th ed., Mosby, 2007

9. Skinner HB. Foot and Ankle Surgery. In: Current Diagnosis and Treatment in Orthopedics, 3 rd ed., California; Orange, 2003, p. 517-9

10. Iversen LD, Clawson DK. Ankle Injuries. In : Manual of Acute Orthopaedic Therapeutics, 3 rd ed.; USA; 198, p. 227

11. Dandy DJ, Edward DJ. Essensial Orthopaedics and Trauma, ed $4^{\text {th }}$, Edinburgh, London, New York, Philadelphia, St Louis, Sydney, Toronto; Churchill Livingstone; 2003, P. 266

12. Sjamsuhidayat R, Jong WD, Penyunting. Buku Ajar Ilmu Bedah, edisi kedua, Jakarta; EGC Penerbit Buku Kedokteran; 2004, hal 1256-7.

13. Carr AJ, Hamilton W. Orthopaedics in Primary Care, 2nd ed. Edinburgh, London, New York, Oxford, Philadelphia, ST Louis, Sydney, Toronto; Elsevier; 2005, p. 88-9

14. Demirel M. et al. Augmented repair of acute tendo Achilles ruptures with gastrosoleus turn down flap. Indian $\mathbf{J}$ Orthop, 2011 
15. Wheeless CR. Achilles Tendon Rupture. In: Wheeles's Textbook of Orthopaedics, 2010

16. Fajar MA. Fractures and Dislocations, 2 nd ed., Dhaka; Sushree; 1990, p 307

17. Metz R. Acute Achilles Tendon Rupture: Minimally invasive Surgery versus non operative Treatment, with Immediate Full Weight Bearing. Design of a Randomized controlled Trial. In: BMC Musculoskeletal Disorders, 2007

18. Bannister GC, Webb JM. Percutaneus repair of the ruptured tendo Achilles.
The Journal of Bone and Joint Surgery, vol. 81-B, No. 5, September 1999

19. Lea RB, Smith L, et. Al. Non-Surgical Treatment Tendo Achilles Rupture. The Journal of Bone and Joint Surgery, vol 54-A, No.7, october 1972, p. 1398-1406.

20. Chapman, Michael W. Tendon Disorders of The Foot and Ankle. In: Chapman's Orthopaedic Surgery, 3 rd ed., California, Texas; Lippincott Williams and Wilkins; 2001, P 3124. 